\title{
CRIATIVIDADE E EDUCAÇÃO
}

Luiz Ricardo Mangili

\begin{abstract}
Resumo
O artigo apresenta como pode ser induzido o conceito de criatividade, de forma a configurar um ensino na ótica pedagógica, desenvolvendo uma rápida análise da criatividade e seus conceitos. Entre os conceitos, tem especial relevância a forma de como o professor pode resgatar, alimentar e trabalhar a imaginação criadora e a capacidade de fantasiar a realidade, de forma do processo criador. O estudo apresentado no artigo é vem a ser complementado por diferentes definições da criatividade, tais como as concepções aos processos produtivos em sala de aula, na relação aluno e professor, relacionados ao pensamento divergente e contrário, inferindo que há uma bipolaridade entre imaginação e pensamento, depois valoriza os potenciais criativos, a natureza e o aluno como foco, visando ao bem individual, segundo os princípios que partem da vida e para a vida educacional e vivencial.
\end{abstract}

Palavras-chave: Criatividade.Arte.Educação.Imaginação.

\section{INTRODUÇÃO}

Rapidamente nos deparamos com grandes transformações no mundo e na educação. Na velocidade como passa o tempo e as novas tecnologias, não conseguimos identificar o novo perfil do profissional do futuro. Essas transformações, na história da humanidade vieram através de um processo dinâmico e criativo, mas, por ironia do destino, não fomos ensinados a ser criativos e sim, buscar a criatividade. (PISKE, 2013)

Assim, começam a surgir neste contexto algumas questões:

Tais como: que lugar deve ter a criatividade em nossos sistemas de educação? Devemos ensinar de forma criativa ou ensinar para a criatividade? A criatividade é reconhecida como uma habilidade prática, que pode ser ensinada e que todos podem alcançar. Ela melhora a autoestima, a motivação e o sucesso escolar. (MIRANDA, 2014, p.107)

Piske (2013) diretamente relaciona esse fato do processo de descoberta e do aprendizado. Conectar-se a esses conceitos anteriormente não relacionados como, 
técnicas, métodos ou ideias, e chegar a um resultado inesperado, será o grande desafio do professor do futuro. As atitudes empregadas às experiências com as descobertas dos novos processos de aprendizado, no ambiente educacional, pode aumentar esse desempenho criativo e dinâmico, induzindo o aluno, com criatividade e dinamismo, a produzir novas ideias através de novas técnicas de ensino que estimulem os pensamentos e as novas formas de aprendizados. Na grande maioria, em nossa atualidade, um número expressivos de professores têm dificuldades em aplicar, acompanhar, induzir à criatividade, ao senso crítico e ajudar os alunos a desenvolverem habilidades do pensamento. Esse processo de estabelecer essas ligações entre o professor e o aluno passa a ser o grande desafio para construírem um currículo criativo.

Guilford (1995), em seus estudos, diz que o pensamento educacional está mais preocupado com "o que é" e não com "o que pode ser". Os Professores da atualidade e do futuro precisam buscar e conhecer novas técnicas que estimulem a curiosidade, a criatividade, o senso de pesquisas, o senso crítico para que possam elevar a confiança e a autoestima dos alunos, assim, equilibrando, conhecimento, criatividade e uma aprendizagem estruturada para gerir grupos, dando atenção a todos os envolvidos nessa jornada. Criatividade no ensino é uma tarefa árdua, mas agradável e profundamente gratificante, quando há essa visão, compromisso, interação e envolvimento entre alunos professores. Os professores criativos estão sempre dispostos a conhecer, entender, estudar e experimentar e a reconhecer a necessidade de aprender com novas, modernas e desafiadoras formas de experiências. Segundo Guilford (1995, p.49) "um ato criativo é uma postura de aprendizagem E que as transformações da informação são a chave para a compreensão".

Por isso, Moraes (2015) aponta para que, os professores estabeleçam um clima afetivo, dinâmico, motivador, incentivador e não de julgamento, mas sim, de assumirem um papel mais voltado às mediações. Entender como os alunos pensam, agem, se interagem é contribuir a partir daí, com os princípios básicos do tema de forma diferente e inovador. O cerne do ensino criativo é o de criar um ambiente favorável e responsável através do entusiasmo e motivação dos professores e da alta valorização e diferenciação dos alunos, levando assim a grandes fatores de maior conhecimento, facilidade de aprendizagem, senso crítico, motivação, crescimento humano e profissional. Pode ser definido como o Ensino de Forma Criativa, ou seja, os professores podem utilizar de 
suas abordagens criativas, inovadoras e dinâmicas para tornar a aprendizagem mais interessante, envolvente, emocionante, motivadora, eficaz e atraente.

\section{A IMPORTÂNCIA DA CRIATIVIDADE NA EDUCAÇÃO}

A criatividade segundo Moran (2017) passou a ser parte fundamental para a educação atual. Pois intenciona que é através da criatividade que o homem consegue superar na sua maioria, os seus problemas. E sabe-se que a influência da criatividade, está diretamente e positivamente ligada às motivações; e também negativamente por uma enorme corrente de diversidade e barreiras que limitam as possibilidades de realização do potencial criativo.

Com relação às barreiras que impedem a pessoa de tirar proveito de suas habilidades criativas podem destacar fatores emocionais, como por exemplo, o medo de ser criticado e cometer erros; destaca também o desejo excessivo de segurança, a falta de confiança nas próprias ideias e capacidades, o próprio comodismo e o receio de parecer ridículo. Nota-se que é comum as pessoas não ter consciência da extensão em que o seu comportamento humano e intelectual é influenciado por tais bloqueios, e também dos recursos que poderia utilizar para sanar esses medos e barreiras (MORAN, 2017).

Segundo Miranda (2014), criatividade é uma qualidade adquirida por pessoas dinâmicas, que arriscam e buscam o desconhecido, inspira-se em informações e têm a sensibilidade de percebê-las de forma diferente. Pessoas criativas demonstram comportamentos diferentes: são curiosas ao extremo, são persistentes, são bem humoradas, são independentes em seus atos e responsáveis por tais, possui rápida capacidade de raciocínio em atividades, fácil percepção, habilidade no formato do aprendizado e ainda são grandes visionárias, já que conseguem prever as consequências possíveis de ocorrer em suas criações por erros ou imprevistos. Isso, ainda por Miranda (2014) pode ser trabalhado pelo professor em sala de aula, podendo agregar e somar no dia a dia; assim, possibilitando um melhor convívio com a sala, proporcionando aulas dinâmicas, incentivando os demais alunos e apresentando melhores resultados de desempenho. 


\section{CONSIDERAÇÕES FINAIS}

Para Moran (2017) é de suma importância colocar uma ponte de ligação entre o aluno e seu professor dentro da sala de aula, sabe-se que a comunicação é primordial para o passo para a evolução. E evoluir significa criar meios para se adaptar e suprir as necessidades e dificuldades, podendo a criatividade induzida em sala ser o esteio dessa relação. Moraes (2015) nos mostra que para criar é preciso imaginar, e nada mais é que o pensamento livre, associado à pura criatividade levada do professor ao aluno sem interferência. É um processo mental que exercita os mecanismos de inteligência, mas existem alunos que precisam de ajuda e apoio para desenvolverem, mas todos possuem. Desenvolver a criatividade passa a ser, em sala de aula, o grande desafio do professor, e, portanto torna-se uma ferramenta pedagógica importante, em que o professor deverá desenvolver em sala.

\section{REFERÊNCIAS BIBLIOGRÁFICAS}

GUILFORD, Joy Paul. A análise da inteligência. 2. ed. Rio de Janeiro: Elsevier, 1995.

MIRANDA, Simão de. Oficina de ludicidade na escola. 1. Ed. São Paulo. Papirus Editora, 2014.

MORAES, Maria Cândida. Transdisciplinaridade Criatividade e Educação. 1. Ed. São Paulo. Papirus Editora, 2015.

MORAN, José Manuel. A Educação que Desejamos. Novos Desafios e Como Chegar Lá. 5ạ ed. Rio de Janeiro. Alta Books, 2017. 